\title{
"Justice must be seen to be done"
}

\author{
By Heike Jung ${ }^{I}$
}

\begin{abstract}
Justice is, in principle, a public affair. Publicity relates to the "fabrication" of justice as well as to the control of the justice system. The principle of publicity has undergone major changes: Expediency and the right to privacy have turned public hearings into a rare event. At the same time, mass media have "sensationalised" court cases, at least the spectacular ones. All this calls for a reappraisal of the publicity principle which will cover somewhat different issues ranging from Court-TV up to "justice and rituals".
\end{abstract}

\section{Introduction}

Our theme has been coined by Lord Hewart in a case concerning bias ${ }^{2}$ and has since turned into one of the most prominent quotations on justice. Today, it may well pass as an indicator for justice tout court. It does indeed trigger off several strands of thought, classical or modern, which lead us to the very essence of justice and its role in society. ${ }^{3}$ With an empirical touch, we could call it an essential socio-psychological prerequisite of the administration of justice. To become more concrete: The dictum reminds us that justice should not take place behind closed doors. Rather, justice is, in principle, a public affair.

In continental Europe the "reformierte Strafprozess" departed from the secret inquisitorial trial and endorsed the publicity principle. Evidently, court procedures have undergone major changes since which tend to undermine the principle if not to do away with it. Nowadays "public" is in this context almost synonymous with the "media". Rehearsing the role of mass media in regard of the justice system we will inevitably be confronted with the question whether it is justified to exclude television and film from court hearings.

Our dictum refers to yet another aspect of justice, namely its presentation, its mise-en-scène. The "fabrication" of justice has always relied on vision and on hearing. This is not just a historical fact, but also a matter of scholarly concern in our days. Ethnography and micro-sociology have entered the courts and the court-rooms. Their discoveries may shed new light on the role of judicial ceremonies and rituals. Here we can also draw from the rich mine of research on rituals, historical and otherwise. 
Hence Lord Hewart's aphorism invites us to a very basic rehearsal of procedure. It ties together philosophical considerations and socio-psychological insights. It calls for theoretical reflection and policy considerations as well. Such an ambitious program cannot be dealt with satisfactorily in a short paper. Still, allow me to present my albeit sketchy personal reading of Lord Hewart's statement.

\section{Why procedure matters}

Justice is a key issue in philosophical and political thought. It figures among the prime normative aspirations of mankind. When speaking of justice we operate at the conceptual level, in the world of ideas so to speak. Yet, justice has an institutional aspect as well which refers to the level of agencies and actors. They are supposed to put across the idea of justice in real life. Whatever concept of justice we have, ${ }^{4}$ it needs to be implemented! By way of implementation, justice becomes tangible. Despite all short-comings, the administration of justice is the everyday approximation of what justice is about. Though we may still cling to our dreams of justice, we know that, for all practical purposes, this is it.

We have entrusted this practical test of justice to the law and to the state. Hence we expect a good delivery. I resist the temptation to enter into the debate about the relationship between law and the state which would eventually lead us to the Kelsenean equation of law and force or to Hobbes' softer version of "auctoritas, non veritas facit legem", both formulae insinuating that law has to be backed by power. Both contentions could be misunderstood in the sense that content does not matter. Instead, I suggest a socio-psychological approach which cares about content and about process. ${ }^{5}$ Particular attention must therefore be paid to the quality of trials and processes since, in a way, they constitute a public forum to justify a verdict. ${ }^{6}$ Socio-psychological knowledge tends to back the traditional notion that at least the public's feeling for justice being done depends on the acceptance of the procedure just as well as on the just result. In consequence, procedural guarantees should not be conceived of as brakes but rather as a prerequisite for justice. ${ }^{7}$ This is not just a theoretical notion, the US-American sociopsychologist Tyler provides empirical support for the triad "Procedural Justice Legitimacy - Compliance". 8

In a way, our sub-title "Why process matters?" needs to be specified: it is not just process that matters but a particular process, namely a fair process. Of course we can keep on arguing indefinitely about the standards of fairness. ${ }^{9}$ Admittedly, agreeing in principle does not imply agreeing on a particular (high) standard. Yet, it is generally accepted that procedure will not allow shortcuts, it will rather be about built-in detours, ${ }^{10}$ call it "schützende Formen", due process or whatever. Of 
course, in the contemporary security haunted climate this contention will not be overly popular on first sight. Yet, in the long run we cannot ignore Justice Brandeis statement: "If the Government becomes a lawbreaker, it breeds contempt for law; it invites every man to become a law onto himself; it invites anarchy." 11

\section{Publicity - Ancient and Modern}

Public trials have a long tradition. Our contemporary notion of the principle of publicity has, however, only been shaped in the era of Enlightenment in reaction to the secret inquisitorial trial. Publicity is a must in the canon of reform principles. No eminent German jurists of this period could refrain from taking a stand. Feuerbach has come forward with an eloquent yet cautious defense of the publicity principle, cautious because this principle happened to be a French export article. He starts out with allegorical reflections about light as a source, element and symbol of good and darkness as the origin, production site and synonym of evil. ${ }^{12}$ Still, Feuerbach has his second thoughts concerning the control potential since the public at large will normally not dispose of the necessary legal expertise. Only when the law has descended to the people, the control power will become real. ${ }^{13}$ Moreover, such a control is, according to Feuerbach, liable to infringe upon judicial independence and the judges ' freedom of judgment. ${ }^{14}$ For him there is no room for a court of public opinion ("ein Gericht der öffentlichen Meinung"). He nourishes a deeply rooted antipathy against what he calls the "Straßenjustiz". ${ }^{15}$ This said he still considers the public's presence to be a constitutional right, since the constitution is at stake not only at the parliamentary level, but also at the level of the courts. ${ }^{16}$

With his meandering line of thought, Feuerbach does not sound overly convinced of the need for the presence of the public. He takes his distance from those who consider the principle of publicity as a panacea against all the flaws of procedure. ${ }^{17}$ However, he senses the winds of change: "Wer längere Zeit in den Hallen der öffentlichen Justiz gewohnt, mit ihr gelebt und sich befreundet hat, wird, ... bald so sehr von ihrem Wesen durchdrungen, daß es ihn zuletzt Mühe kostet, auch nur die Vorstellung von dem möglichen Daseyn einer nicht öffentlichen Gerechtigkeitspflege wieder zur Klarheit zu bringen." ${ }^{, 18}$ It seems to me that Feuerbach's reservations are rather an expression of political restraint. He is in favour of change, yet he deems it inappropriate to give all the credit to the French and to advocate a wholesale takeover. Be this as it may: the era of Enlightenment had transformed the principle of publicity into an indicator of political culture and of the democratisation of the court system. What, in medieval times, used to be - 
Justice must be seen to be done - a prerequisite of the functioning of the legal system as such was now rather perceived of as part of the constitutional legitimation of the judicial system.

In the end, the principle of publicity carried the day. However, it was only applied to the hearing. Of course, its consecration in the German Constitution of Courts Act in 1877 did not put an end to the debate. Revisiting the principle today, we have to acknowledge major changes which call for its reappraisal. Rivaling interests, such as privacy, have become more prominent and, with the consolidation of the judiciary, there is more room to pay respect to them. Also, the general direction of publicity has changed. Whereas, traditionally, the public used to be identified with individual visitors, mass media has nowadays largely taken over. This gives rise to a new set of issues culminating in the question whether TV should be allowed into the court room. Finally, the changes in the procedural set-up also call for a reappraisal of the publicity principle. In Germany, hearings take place in only $20 \%$ of all indictable cases. ${ }^{19}$ Discharges under condition and written penal orders account for the rest. Moreover, plea bargaining practices tend to undermine the publicity principle even in the remaining cases of public hearings.

\section{Publicity vs. privacy}

The individuals who are involved will in the majority of cases not like the publicity of a criminal trial. As a matter of fact, being on display will often be considered a punishment in itself. Publicity can have a stigmatising effect. In particular, spectacular trials may, due to the media coverage, have devastating effects for the accused and the victims irrespective of the outcome.

We are heading for a complex balancing of interest. On the one hand, trials can no longer take place behind closed doors. On the other hand, the respect for human dignity requires that the process should not be handled as a show yielding to base sensationalism. It is of course difficult to draw the line. A criminal trial will inevitably expose the participants in public and to the public as long as we adhere to the principle that justice must be seen to be done. Yet, where is a borderline which should not be transgressed? In particular, the protection of vulnerable witnesses may call for special precautions which range from the exclusion of the public to the use of "surrogate evidence", i.e. introducing into the hearing audio-visual testimony gathered in the pre-trial phase. This transfer of evidence from the pre-trial phase raises very principled questions regarding the structure of the procedure, not necessarily regarding the publicity principle but rather regarding the principle of immediacy and the right to confront witnesses. Here, we 
stand at crossroads: If we keep promoting and extending the possibility of such transfers, the decision will only formally be taken at the end of the hearing. In actual fact, it will be pre-fabricated during the preliminary investigation. This will not be without consequences for the defense. Also, more transparency will be needed during the phase of the preliminary investigation. Already Feuerbach had warned that the public hearing could not compensate for all the detriments of a secret pre-trial phase. ${ }^{20}$

\section{Publicity and the media}

Mass media have come to be an omnipresent, almost irresistible power today. Today, mass media have more or less taken over as the main guarantor of the publicity principle. It may therefore come as a surprise that some jurisdictions, among them Germany, still do not allow photographs or films to be taken during the court session. Stubborn resistance or wise reluctance? This has been an issue in Germany for some time. As a matter of fact, this is already my fourth go at the topic. Revisiting my own positions of $1986,{ }^{21} 2004^{22}$ and $2006,{ }^{23}$ it looks as if I had become more permissive each time. Has time come for me to endorse court TV unconditionally? ${ }^{24}$

Let us rehearse the arguments. It is of course difficult to explain why the media which have turned into the information and control agency should be barred with their perhaps most potent means of expression from the court room. Also, the different fictional court-room shows which are running on German TV confirm the great interest the general public takes in such matters. Moreover, should we really write off the educational potential of an audio-visual presentation of court sessions? And finally: it seems almost peculiar that we should rely on hearsay when it comes to the mise-en-scène of justice whereas audio-visual coverage of other social events is more or less self-explanatory today. How will contemporary court proceedings be accessible to future generations without any authentic audio-visual evidence? Of course, the counterarguments cannot be dismissed light-handedly. Serious detriments for the discovery of the truth, sensationalism, loss of rationality, a distorted picture of justice, stigmatization are perhaps the key objections.

In Germany, the controversy has recently been fueled by the President of the Federal Constitutional Court Voßkuhle who is inclined to open the hearings at his court to the cameras. ${ }^{25}$ In turn, the President of the Federal Supreme Court Tolksdorf has argued in favor of the status quo. ${ }^{26}$ This goes to show that the answer to our question will, to a certain extent, depend on the branch of the judiciary we are talking about. Also, this is a generation problem. The younger generation may not 
be afraid of the potentially distorting effects of the presence of cameras, since it is more used to them. Transition periods may call for experimental designs, for a "policy of gradualism". 27 The German Federal Constitutional Court already allows cameras in when it is handing down its judgments. Parliamentary investigation committees may also allow cameras to be present during their proceedings.

I fancy we could even include criminal cases. In a first step we should open the court room for documentation purposes following the French example. In France, which has adopted a rather restrictive approach with the so-called "loi Badinter" of 1985 , allowing court sessions to be filmed only in cases of historical interest, ${ }^{28}$ the authorities have tolerated (documentary) films to be taken during the audience with the consent of the persons involved. The most prominent production, Depardon's " $10^{\mathrm{e}}$ chambre, instants d'audience", was even presented at the Cannes Film Festival in 2004. This film gave me illuminating insights into the French proceedings. Of course, it is difficult to tell whether the recording produced tensions on the part of the participants. I believe to have detected some overreactions, but rather on the part of the professionals. But on the whole, this film gave me the impression of a straight-forward and discreet matter- of- fact production.

Though it may seem advisable to gain experience first with the more controlled and controllable documentary approach before going further, the experiences with court TV in many other countries - including Finland and Norway show that an absolute prohibition of court TV is perhaps out of step with the present-day social reality of a "Facebook-society". The risk of sensationalism exists with or without court TV.

\section{The regression of the public hearing}

Public hearings have become a rare event and, if they take place, one cannot be sure that the decisive steps take place in public. At least with procedures of an inquisitorial type, this is not altogether new since such procedures have always relied heavily on the more or less secret preliminary investigation making the public hearing sometime look like a mere ratification procedure. Certain tendencies give the impression that we are returning to the times of a written or secret procedure. Of course, preliminary investigations do not take place without resonance. In spectacular cases, the prosecution, the defense and the victim will express themselves in public, ${ }^{29}$ often enough with the intention to influence the ongoing procedure. Such moves may allow drawing some general inferences, yet they do not shed much light on specific procedural actions. To impose, in the inquisitorial tradition, a rigid regime of secrecy for this phase of the procedure like the French 
do (cf. Art. 11 Code de procédure pénale), may be overstating the point. It is clear, though, that preliminary investigations should, normally, not take place in public. Too much publicity will hurt the proceedings at this stage. Yet, too much secrecy may also be counterproductive. ${ }^{30}$ The public has a right to be informed. It is customary that the police and the prosecution services provide information on ongoing investigations. Still, this is a delicate manoeuvre, since they will have to strike the balance between the presumption of innocence and the access to information. As a general orientation we have to watch out that the prosecution authorities do not get carried away by a "hunting spirit". U.S.-American practices of presenting suspects as a "trophy" in public - see the recent Strauss-Kahn case which has given rise to a vivid and critical discussion of the so-called "perpwalk"31 - show, however, that the shield of protection offered by the presumption of innocence varies from country to country. Despite such differences, the "medialisation" of the preliminary investigation and its instrumentalisation for preventive purposes is being practised all-over much to the detriment of the procedural balance envisaged by the fairness principle. ${ }^{32}$

Though the preliminary investigation is, at least in the more serious cases, threatened by too much publicity the large amount of discharged cases tends to produce an enormous information gap, since the public will in these cases have no or little information on the reasons for such a disposal. Of course, the prosecution services and the judiciary would be overburdened if we expected them to justify each and every decision at length. Such means of disposition have been introduced to save time and resources. Yet, at least for the sake of criminal policy, a practice of publication, in an anonymised form, of representative cases should be developed. Such a practice would help promoting the predictability of decisionmaking and to counteract the impression that such decisions are being taken arbitrarily. ${ }^{33}$

The effectivity principle does not stop at the doors of the court room. In consequence, jurisdictions throughout the world have introduced or legalised regimes of a negotiated justice. Internationally known under the name of plea bargaining, such practices allow for an exchange between a milder punishment on the one hand and a more stream-lined procedure on the other. Their admissibility and potential range are still a matter of controversy. ${ }^{34}$

It is evident that plea bargaining raises many first principle questions of procedure and of criminal law as such. ${ }^{35}$ Here, I shall restrict myself to address the frictions with the publicity principle. Negotiations tend to take place outside the public hearing, in the judge's chamber or on the phone. This could nourish distrust in the judiciary, the raison d'être for the publicity principle. It could give the 
impression that a privileged group of defendants may take advantage of this informality. On this background, the German law requires that the "agreement" will have to be disclosed during the public hearing. Yet, such an ex post facto disclosure could be discredited as mere tokenism. This said, we should, however, remember that the publicity principle does not require that every procedural step should be taken under the eyes of the public. In a way, such practices may help promote the understanding that publicity is only an expression of transparency as sort of meta-principle. ${ }^{36}$ Transparency cannot only be achieved by publicity. For the sake of transparency a well documented record of the negotiation might suffice as long as it will enable the public to check the fairness of the bargaining proceedings.

\section{Rituals revisited ${ }^{37}$}

Rituals have become a matter of debate again, not only in the scientific community, but also in public discourse. The revival of rituals has made its way immediately into the justice debate which, only a generation ago, had concentrated on the deconstruction of rituals. This holds true in particular for France. The first to take judicial rituals seriously again was Antoine Garapon who propagates a modernised version of rituals: "Il était donc faux de qualifier le rituel judiciaire d'archaique ... Il faut repeupler la vie publique avec de nouveaux symboles, des rites efficaces, signifiants et maîtrisés." ${ }^{38}$ Whereas Garapon is striving for "des symboles plus vrais", i.e. for a certain dynamisation of rituals, Desprez presents, some 25 years later, an almost nostalgic (re-)appraisal of rituals. He considers them to be constituing elements of "the majesty" of the justice system. The legitimacy of judges depended not only but also on rituals which transform rendering justice into a transcendental exercise. ${ }^{39}$ According to Desprez this comes to bear in particular in jury trials to which he consecrates the first part of his thesis, whereas he diagnoses, in the second part, a constant "deritualisation" for the more "bureaucratic" types of trial. This dichotomy is certainly overstating the point; this may be owed to the French tradition that every academic presentation should have two parts.

A rationalist who nevertheless tends to be captured by rituals right away, a former judge familiar with the judicial ornament who nevertheless tried to convince by way of argument, I am of course tempted to engage into a lengthy argument. Yet my concern today is of a more limited nature. I am not going to delve onto the reasons for this revival of interest in rituals. Nor am I going to rehearse definitional issues. Such a rehearsal would in any event only confirm that the borderlines between ritual, rites, ceremony and symbols are blurry. Our slo- 
gan "Justice must be seen to be done" suggests a functional approach: We are invited to find out whether and to which extent rituals help to make justice visible.

Speaking of judicial rituals is a very general "façon de parler". The judicial ritual is composed of many elements ranging from gowns, a formalised exchange of arguments within the particular setting of a court-room to the "architecture parlante" of court buildings. Taken together this ensemble transforms justice into a performance which is distinct from everyday life, it creates a world of its own, a detached micro- cosmos. The mise-en-scène attracts and focalises attention, it provides a certain demarcation from everyday life and a structured set for a rather formalised interaction. The mise-en-scène orientates and mobilises a traditional pre-understanding: we realize immediately that this is a court session. Thus, rituals underscore the institutional quality of the process.

Let us face it: we cannot and should not dispense with this orientation function of rituals. We should, however, beware of excessive ritualisation which, as we know from Merton, is a synonym for stand-still. ${ }^{40}$ Too much rituality will give the impression that the courts operate as a self-perpetuating institution. Also, rituals are not sacrosanct, but liable to change. Interestingly enough, modern court architecture has taken up the theme of visibility which is certainly more appropriate for a democratic society than the majestic orchestration of traditional court buildings. ${ }^{41}$

\section{Conclusion}

The present-day reading of the public/private dichotomy offers a complex picture. It seems to me that, in particular within the younger generation, there is a wide-spread longing for public stardom or at least for public resonance fostered not only by television but also by modern internet communication habits and systems. In political life, the borderline between private and public has become blurry anyway. Often enough, politicians will be tempted to instrumentalise their private life for political purposes.

The justice systems seem to move into the opposite direction. Having "gone public" in the era of Enlightenment much of the administration of contemporary justice takes place behind closed doors. Publicity has its price: Public hearings are costly and difficult to handle. Some of the modifications of the publicity principle have been introduced on purpose. Others have been the consequence of structural changes. Revisiting the publicity principle is a timely exercise. We have to cope with divergent tendencies. More visibility on the one hand, less visibility on the other? Why not, if the transparency of the institution as a whole is guaranteed. 
It may well be that in the modern information society we no longer need the open door, since nothing will remain secret anyway, and that, correlatively, an increasing need is being felt for protection against too much publicity. Still, justice and publicity will remain inextricably linked. The experience in Columbia with "invisible judges" 42 shows that something is wrong with the administration of justice if the judiciary operates in the dark.

Trials form part of those mechanisms which help generate social cohesiveness. Such mechanisms depend on visibility. Otherwise, the lessons of justice will not be learnt. Likewise, rituals will only string a chord if they are orchestrated in front of an audience. Sensual experience still matters when it comes to grasp the idea of justice.

\section{Notes}

1. Professor emeritus, University of Saarland. Former chair of criminal law, criminal procedure, criminology and comparative criminal law.

2. R. v. Sussex Justices, ex parte McCarthy (1924) $1 \mathrm{~KB} 256,259$ Quoted in full its reads: “... that it is not merely of some importance but it is of fundamental importance that justice should not only be done, but should manifestly and undoubtedly be seen to be done."

3. According to Maher, Natural Justice as Fairness, in: Essays for Tony Honoré, Clarendon Press, Oxford 1986, p.103, it forms an integral part of the natural justice requirements for any procedure.

4. On the different options cf. the overview by Campbell, Justice, Macmillan, Houndsmill et al. 1988 .

5. See also Neumann, Materiale und prozedurale Gerechtigkeit, ZStW 101 (1989), p. 52.

6. Jackson, The Function of the Criminal in Legal Inquiry, in: Duff et al. (eds.), The Trial on Trial. Vol 1, Hart, Oxford and Portland 2004, p. 121, 129.

7. Hassemer, Konstanten kriminalpolitischer Theorie, in: Festschrift für Lange, de Gruyter, Berlin/New York 1976, p. 501, 518 et seq.

8. See Tyler, Why People Obey the Law, Princeton University Press, Princeton/Oxford 2006, p. 270.

9. Gaede 's rehearsal of the fairness principle enshrined in Art. 6 of the European Convention of Human Rights runs up to 1000 pages; Gaede, Fairness als Teilhabe, Duncker \& Humblot, Berlin 2007.

10. Salas, Etat et droit pénal, Droits No. 15 (1992), p. 77 78. Packer, The Limits of the Criminal Sanction, Stanford University Press, Stanford 1968, p.163 compares the due process model with an obstacle course, whereas he associates the crime control model with an assembly line.

11. Dissenting opinion in Olmstead v. the United States, 277 U.S. 438, 485 (1928).

12. Feuerbach, Betrachtungen über die Öffentlichkeit und die Mündlichkeit der Gerechtigkeitspflege, Heyer, Gießen 1821, p. 87.

13. Feuerbach (note 11), p. 152.

14. Feuerbach (note 11), p. 156 et seq. 
15. Feuerbach (note 11), p. 158.

16. Feuerbach (note 11), p. 169.

17. Feuerbach (note 11), p. 16.

18. Feuerbach, Betrachtungen über die Öffentlichkeit und Mündlichkeit der Gerechtigkeitspflege, Vol. 2, Über die Gerichtsverfassung und das gerichtliche Verfahren Frankreichs, in besonderer Beziehung auf die Öffentlichkeit und die Mündlichkeit der Gerechtigkeitspflege, Heyer, Gießen 1825, p. 205.

19. Heinz, Der Strafbefehl in der Rechtswirklichkeit, in: Festschrift für Müller-Dietz, Beck, München 2001, p. 271, 300.

20. Feuerbach (note 17), p. 396: "Allein hier handelt es sich nicht um die Vorzüge des öffentlich mündlichen Hauptverfahrens, sondern um die Nachteile des heimlichen schriftlichen Vorverfahrens; und da wäre es sehr voreilig, aus jenen Beispielen den Schluß zu ziehen: die Nachteile des geheimen Vorverfahrens würden in ihren Wirkungen durch das ihm folgende öffentliche Hauptverfahren wieder aufgehoben."

21. Jung, Öffentlichkeit - Niedergang eines Verfahrensgrundsatzes?, in: Gedächtnisschrift für Hilde Kaufmann, de Gruyter, Berlin/New York 1986, p. 891, 908 et seq.

22. Jung, Fernsehberichterstattung aus der Hauptverhandlung, in: Bannenberg u.a., AlternativEntwurf Strafjustiz und Medien (AE-StuM), Beck, München 2004, p. 102.

23. Cf. my Richterbilder. Ein interkultureller Vergleich, Nomos, Baden-Baden 2006, p. 135.

24. As a matter of fact, my present position has advanced again under the impression of Ragna Aarli `s comments during the discussion of my paper.

25. See Süddeutsche Zeitung of November 26, 2010.

26. Cf. Süddeutsche Zeitung of November 29, 2010.

27. Expressly favored by the dissenting vote in the decision of the German Federal Constitutional Court on the constitutionality of the prohibition in $\S 169$ subs. 2 of the Constitution of Courts Act (BVerfGE 103,44, 79). The majority has endorsed the status quo; it has not declared, though, that forbidding court TV is a constitutional "must".

28. For details cf. Britz, Fernsehaufnahmen im Gerichtssaal, Nomos, Baden-Baden 1999, p. 150 et seq. With the exception of crimes against humanity the material will have to remain in the archives for at least 30 years.

29. Cf. Volk, Medienöffentlichkeit, in: Nelles/Vormbaum (eds.), Strafverteidigung in Forschung und Praxis, Berliner Wissenschafts-Verlag, Berlin 2006, p. 47, 50.

30. Cf. the balanced analysis by Weigend, Ermittlungsverfahren im Lichte der Medienöffentlichkeit? In: Festschrift für Rolinski, Nomos, Baden-Baden 2002, p. 253.

31. E.g. Süddeutsche Zeitung of May 18, 2011, p. 4 and 11; Der Tagesspiegel of May 18, 2011, p. 6; Le Monde of May 21, 2011, p. 4; Frankfurter Allgemeine Zeitung of May 20, 2011, p. 3.

32. See the critical analysis by Zabel, "Öffentlicher Pranger" und reformierter Strafprozess, Goltdammer`s Archiv für Strafrecht 2011, p. 347.

33. Cf. Rengier, Veröffentlichung und Überlassung abschließender strafgerichtlicher und staatsanwaltlicher Entscheidungen, in: Bannenberg u.a., Alternativ-Entwurf Strafjustiz und Medien (AE-StuM), Beck, München 2004, p. 134, 145 et seq. 
34. Cf. The comparative overview by Rosenau, Plea bargaining in deutschen Strafgerichtssälen: Die Rechtsvergleichung als Auslegungshilfe am Beispiel der Absprachen betrachtet, in Festschrift für Puppe, Duncker \& Humblot 2011, p. 1597.

35. Cf. Jung, Plea Bargaining and its Repercussions on the Theory of Criminal Procedure, European Journal of Crime, Criminal Law and Criminal Justice 1997, p. 112.

36. For a general account of the principle of transparency cf. Bröhmer, Transparenz als Verfassungsprinzip, Mohr Siebeck, Tübingen 2004. Bröhmer alludes only briefly to the relationship between "publicity" and "transparency". In focussing on the broader term "public" he arrives at the opposite ranking order (op. cit. p.19). A distinction between "öffentlich" and "Öffentlichkeit" would have allowed him to discover the potential of transparency as the real meta-principle in relation to publicity.

37. I am drawing from previous papers: cf. Justiz und Ritual, in: Jung/Luxenburger (eds.), Festschrift für Egon Müller, Nomos, Baden-Baden 2008, p. 319; Rituals Forever?, European Journal of Crime, Criminal Law and Criminal Justice 2010, p. 67.

38. Garapon, Bien juger. Essai sur le rituel judiciaire, Editions Odile Jacob, Paris 1997, p. 321 et seq.

39. Desprez, Rituel judiciaire et procès pénal, L.G.D.J., Paris 2009.

40. Merton, Social Theory and Social Structure, Revised and Enlarged Edition, Free Press, Glencoe 1957, p.149-153.

41. The building of the German Federal Constitutional Court at Karlsruhe is a classical example for this new style; see Bürklin, Mit einem Hauch von Internationalität und Modernität, in: Verein der Richter des Bundesverfassungsgerichts e. V. (Hrsg.), Das Bundesverfassungsgericht in Karlsruhe, Birkhäuser, Basel/Boston/Berlin 2004.

42. E.g. Aponte, Krieg und Feindstrafrecht, Nomos, Baden-Baden 2004, p. 68. 